\title{
Swoistość zapożyczeń z języków blisko spokrewnionych (na przykładzie zapożyczeń czeskich i wschodniosłowiańskich w języku polskim)
}

Słowa klucze: zapożyczenia formalnosemantyczne, kalki strukturalne, zapożyczenia (kalki) semantyczne, adaptacja fonetyczno-morfologiczna zapożyczeń

Jak wiadomo, wynikiem obcych wpływów językowych są na płaszczyźnie leksykalnej zapożyczenia formalnosemantyczne, kalki strukturalne i zapożyczenia (kalki) semantyczne. W pierwszym wypadku mamy do czynienia $\mathrm{z}$ przejęciem obcego wyrazu w jego oryginalnej postaci fonetycznej wraz z jego znaczeniem. W trakcie przejmowania następuje, oczywiście, adaptacja obcej postaci fonetycznej wyrazu do wymogów fonetyczno-morfologicznych języka zapożyczającego. Sprawa jest banalna, dla porządku myślowego rozpatrzmy jednak stosowny przykład.

W XVII wieku zaczęła do Polski przenikać moda francuska. Część (podówczas jeszcze bardzo niewielka) naszych przodków porzuciła podgolone sarmackie czupryny i zastąpiła je nowym wynalazkiem: fryzurą ze sztucznych lub naturalnych włosów umocowanych na specjalnej siatce. Jak to często bywa, wraz z nową rzeczą napłynęła jej oryginalna nazwa - francuski wyraz perruque. Prześledźmy proces jego adaptacji do wymogów fonetyczno-morfologicznych polszczyzny. 
Na płaszczyźnie fonetycznej proces ów polegał, jak zawsze w takich wypadkach, na zastąpieniu fonemów obcego wyrazu identycznymi lub relatywnie najbliższymi pod względem fonetycznym fonemami języka ojczystego. Francuskie $p$ niczym się nie różni od polskiego $p$, zostało więc nim zastąpione; $e \mathrm{w}$ wyrazie perruque jest otwarte i też się w zasadzie nie różni od polskiego $e$ (zresztą dla francuskiego $e$ zamkniętego najbliższym fonetycznie polskim dźwiękiem jest również e), nie nastręczało więc kłopotów w procesie asymilacji francuskiego wyrazu. Francuskie $r$ w XVII wieku było jeszcze głoską przedniojęzykową (wymowa języczkowa upowszechniła się dopiero po Wielkiej Rewolucji Francuskiej), nie różniło się więc niczym od polskiego $r$ (a nawet jeśliby już wówczas było wymawiane w sposób języczkowy, to i tak jego najbliższym fonetycznie odpowiednikiem byłoby polskie przedniojęzykowe $r$ ). Dotąd adaptacja francuskiego wyrazu przebiegała więc gładko. Trudności pojawiły się dopiero przy $u$. Francuskie $u$ jest samogłoską przednią labializowaną. Pod względem artykulacji języka najbliższe jest mu więc polskie $i$, natomiast pod względem artykulacji warg - polskie $u$. Toteż polszczyzna czasem przejmuje francuskie $u$ jako $i$ (punaise - pinez$k a$ ), niekiedy zaś jako $u$ (lunette - luneta), a najczęściej wybiera drogę pośrednią, co daje w wyniku iu (buste - biust). W wypadku wyrazu perruque doszło do substytucji francuskiego $u$ przez polskie $u$. Francuskie $q u$ niczym się nie różni od polskiego $k$, zostało więc przez nie zastąpione. Wygłosowe $e$ wyrazu francuskiego było już w XVII wieku nieme, tzn. nie odpowiadała mu już żadna wartość fonetyczna. W zakresie fonemów suprasegmentalnych adaptacja polegała na przesunięciu francuskiego akcentu oksytonicznego na sylabę przedostatnią zgodnie z obowiązującym w XVII wieku miejscem akcentu w polszczyźnie.

Wynikiem opisanego procesu byłaby forma *peruk. Tutaj jednak obserwujemy ingerencję płaszczyzny morfologicznej. Forma *peruk musiałaby być w języku polskim rzeczownikiem rodzaju męskiego (wszystkie rzeczowniki zakończone na spółgłoskę twardą są w języku polskim rodzaju męskiego). Tymczasem wyraz francuski jest rodzaju żeńskiego (une perruque) i dla dwujęzycznych, doskonale władających francuszczyzną siedemnastowiecznych elegantów noszących peruki *ten peruk był nie do pomyślenia. Forma, która powstała w wyniku adaptacji fonetycznej, została zatem włączona do paradygmatu rzeczowników rodzaju żeńskiego za pomocą wygłosowego $a$. 
Ostatecznie francuski wyraz perruque przybrał więc w polszczyźnie postać peruka.

Jak więc widać z omówionego wyżej przykładu, w wypadkach takich jak peruka mamy do czynienia z przejęciem obcej postaci fonicznej wyrazu (perruque) oraz dostosowaniem jej do wymogów fonetyczno-morfologicznych języka zapożyczającego (peruka), i jednocześnie z przejęciem obcego znaczenia ('fryzura ze sztucznych lub naturalnych włosów umocowanych na specjalnej siatce'). W procesie zapożyczania znaczenie może ulec pewnej modyfikacji, zwykle zwężeniu zakresowemu (bądź redukcji znaczeń w wypadku wyrazów polisemicznych: często zapożycza się tylko wybrane znaczenie/znaczenia wyrazu obcego, co jest podyktowane potrzebami nominatywnymi i/lub ekspresywnymi języka zapożyczającego). Odrębną kwestią jest rozwój semantyczny (też najczęściej zmierzający do zwężenia znaczenia) wyrazu zapożyczonego już na gruncie języka zapożyczającego (zob. Walczak 1980 (tam też omówienie starszej literatury przedmiotu), 1983, 1989).

Zupełnie inną technikę przejmowania obcych wyrazów do języka zapożyczającego reprezentują kalki strukturalne (słowotwórcze). Technika ta polega, jak wiadomo, na dosłownym, literalnym przekładzie składających się na zapożyczony wyraz morfemów, czyli - innymi słowy - na zastąpieniu ich odpowiadającymi im pod względem znaczeniowym (funkcjonalnym w wypadku morfemów gramatycznych) morfemami rodzimymi, czyli - jeszcze inaczej - na odwzorowaniu wewnętrznej struktury przejmowanego wyra$\mathrm{zu}$ (warunkiem przejęcia obcego wyrazu w postaci kalki strukturalnej jest więc jego strukturalna przejrzystość). Przykładowo, francuski wyraz demimonde został odwzorowany w postaci pótświatek (demi znaczy 'pół', mon$d e$ - 'świat', sufiks - ek jest tutaj formantem czy współformantem o funkcji wyłącznie strukturalnej); na marginesie dodajmy, że musiał w polszczyźnie XIX wieku istnieć *d(e)mimond (zapożyczenie formalnosemantyczne), skoro został podówczas zaświadczony derywat demimondówka 'kobieta z półświatka'. Kalka (pótświatek) składa się więc z morfemów rodzimych, toteż zwykle użytkownicy języka nie dostrzegają w niej niczego obcego i nie traktują jej jako wyrazu obcego pochodzenia.

Kalki jako typ zapożyczeń o wiele słabiej niż zapożyczenia formalnosemantyczne wyodrębniają się w zasobie wyrazowym języka zapożyczającego. W części wypadków specjaliści (ale niekoniecznie przeciętni użytkownicy języka) dostrzegają obcość ich budowy (modelu konstrukcyjnego). Rozpatrz- 
my stosowny przykład. Istnieje w polszczyźnie odziedziczony z prajęzyka słowiańskiego rodzimy model konstrukcyjny (typ słowotwórczy), który można opisać następująco: wyrażenie przyimkowe + formant $-' e\left(\leftarrow *_{- \text {-bje })}=\right.$ nazwa miejsca (nomen loci), na przykład poddasze (< pod dachem), nadbrzeże ( $<$ nad brzegiem), gwarowe zapłocie $(<$ za płotem). Derywat od wyrażenia przed pokojem winien zatem brzmieć przedpokoje - i taka forma, rodzaju nijakiego, widnieje w słowniku Knapiusza z 1621 roku. Był to jednak neologizm Knapiusza, który - jak to najczęściej bywa z neologizmami leksykonowymi - nie przyjął się (mimo poprawnej budowy, tzn. mimo zgodności z rodzimym modelem konstrukcyjnym). Ustalony w drugiej połowie XVIII wieku przedpokój zdradza swoją postacią zależność od obcego wzoru. Chronologia i okoliczności historyczne (kontekst kulturowy) każą upatrywać tego wzoru we francuskim wyrazie antichambre. Dodajmy, że francuskie antichambre jest już też kalką łacińskiego antecamera; wyraz łaciński był kalkowany także w innych językach europejskich, na przykład włoskim w postaci anticamera (stąd w polszczyźnie zapożyczenie formalnosemantyczne antykamera, podstawowa nazwa przedpokoju w XVI, XVII i jeszcze w pierwszej połowie XVIII wieku) czy niemieckim w postaci Vorzimmer.

Jednak nie wszystkie kalki realizują model konstrukcyjny niezgodny z systemem słowotwórczym języka zapożyczającego. Model ten jest, oczywiście, pod względem genetycznym zawsze obcy, ale czasem bywa zgodny z jakimś modelem rodzimym - wtedy kalka synchronicznie niczym się nie różni od wyrazu rodzimego, derywatu lub compositum. Wówczas dopiero gruntowne badania diachroniczne mogą ustalić właściwy jej status i charakter. Ciagnik ze względu na budowę mógłby być wyrazem rodzimym - dopiero szczegółowe badania, ujawniające okoliczności jego powstania (powstał na fali polszczenia obcych terminów naukowych, technicznych i zawodowych, w celu zastąpienia funkcjonującego już w polszczyźnie wyrazu traktor, którego wewnętrzną strukturę odwzorowuje: ciag- tłumaczy łacińską podstawę traktora - jest nią czasownik traho, trahere, tractus 'ciągnąć', -nik odwzorowuje formant -tor), pozwalają go uznać za kalkę. Ogólnie biorąc, kalki są trudne do zidentyfikowania i w języku polskim jest, w moim przekonaniu, wiele dotąd w literaturze przedmiotu nie zidentyfikowanych kalk (o kalkach z perspektywy teorii i metodologii badań zob. Obara 1989).

Dla pełności obrazu przypomnijmy jeszcze mechanizm zapożyczeń (kalk) semantycznych - na klasycznym, podręcznikowym przykładzie. W najdaw- 
niejszej polszczyźnie wyraz zamek oznaczał tyle co 'przyrząd służący do zamykania czegoś', gdyż jest to derywat od czasownika zamknqć (alternacyjne postaci zamek- / zamk- (zamek, zamknqć) / zamyk- (zamykać) itd. układaja się w regularny szereg o prasłowiańskiej genezie, por. usech- / usch- (usecht, uschnać) / usych- (usychać) itd.). W oddziałującym na polszczyznę średniowieczną języku niemieckim zamkowi odpowiadał semantycznie schloss (od schliessen 'zamknąć'; dodajmy, że derywat od schloss, a mianowicie schlosser 'etymologicznie: rzemieślnik zajmujący się wyrobem i naprawą zamków', zapożyczyła polszczyzna w postaci ślusarz). Ale niemiecki wyraz schloss, oprócz znaczenia 'przyrząd służący do zamykania czegoś', miał (i ma) jeszcze drugie znaczenie: 'rodzaj budowli obronnej'. I ten stosunek znaczeniowy, charakterystyczny dla języka niemieckiego, na skutek jego wpływu na polszczyznę został przeniesiony na grunt polski, wprowadzony do języka polskiego - i w wyniku tego polski wyraz zamek też zaczął oznaczać 'rodzaj budowli obronnej'. Tak więc starsze, pierwotne znaczenie wyrazu zamek jest rodzime, czysto polskie, drugie natomiast zostało zapożyczone z języka niemieckiego. Ostatecznie zatem mamy tutaj sytuację podobną jak w wypadku przedpokoju: mimo zewnętrznej swojskości wyrazu związek łączący jego formę i znaczenie oparty jest na obcym wzorze.

Jak wynika z przypomnianych tu różnych technik zapożyczania wyrazów (i znaczeń) z języków obcych, zapożyczenia formalnosemantyczne bardzo wyraźnie się przeciwstawiają kalkom. Nie można mieć wątpliwości, że *d(e)mimond to zapożyczenie formalnosemantyczne, a pótświatek to kalka. Rozstrzyga o tym obcość w pierwszym, a rodzimość morfemiczna w drugim wypadku. Szczególnie wyrazistych przykładów dostarczają tu germanizmy, gdyż na skutek zrozumiałej purystycznej postawy wobec dziewiętnastowiecznych wpływów niemieckich wiele ówczesnych germanizmów formalnosemantycznych zostało zastąpionych kalkami (które przez ogół użytkowników języka nie były odczuwane jako germanizmy). Nie można mieć wątpliwości, że bryftrygier to zapożyczenie formalnosemantyczne, a listonosz to kalka, że banhof to zapożyczenie formalnosemantyczne, a dworzec kolejowy to kalka (w tym wypadku niedokładna - odwzorowanie niemieckiego compositum w postaci wyrażenia). Toteż można by sądzić, że w ogóle nie istnieje lingwistyczny problem odróżniania zapożyczeń formalnosemantycznych od kalk.

Tymczasem $\mathrm{w}$ istocie problem taki się pojawia $\mathrm{w}$ wypadku przejmowania obcych wyrazów z języków blisko spokrewnionych. Ukażemy to na przykła- 
dzie zapożyczeń czeskich i rosyjskich (wyrazy rosyjskie mają często dokładne odpowiedniki w innych językach wschodniosłowiańskich, stąd ostrożność w sformułowaniu tytułu niniejszej pracy) w języku polskim. Pochodzą te przykłady zarówno ze źródeł leksykograficznych, jak i z monografii dotyczących zagadnienia wpływów czeskich i rosyjskich w polszczyźnie. Przykłady zapożyczeń czeskich pochodzą z dawnej (do XVI wieku) polszczyzny i zostały, co oczywiste, przejęte ze starej czeszczyzny (w polszczyźnie $z$ reguły się nie utrzymały, a ich czeskie pierwowzory też nie zawsze przetrwały w języku czeskim do dziś): golicz 'balwierz’ z czes. holič, łęczyszcze 'łuk, brama tryumfalna w kształcie łuku' z czes. lučišče, mięsopust 'zapusty, ostatki' z czes. masopust, obłocznica 'szatnia, westybul' z czes. oblačnice, pierworodzeniec 'syn pierworodny' $\mathrm{z}$ czes. prvorozenec, piędzimężyk 'karzeł' z czes. piedimužik, pogrobek 'pogrobowiec' z czes. pohrobek, przesięgnać 'przewyższyć' z czes. přesáhnouti, sqdzki 'sądowy' z czes. soudský itp. (Urbańczyk (red.) 1953-2002, Mayenowa (red.) 1966-2004, Basaj, Siatkowski 2006). Przykłady rosyjskie to skutek oddziaływania języka rosyjskiego na polski w okresie zaborów i, po kilkudziesięcioletniej przerwie, w epoce PRL-u: obróbka z ros. obrabotka, przejaw z ros. projav, przewózka 'przewóz' z ros. perevozka, uczqstek (w XIX wieku wyraz o wielu znaczeniach: 'cyrkuł, komisariat policji', 'obwód w mieście, dzielnica', 'rewir, odcinek drogi', 'kawałek ziemi, działka', 'odcinek frontu, pozycja') z ros. učastok, wyrozchodować 'wydać, wydatkować' z ros. izraschodovat', zakaska z ros. zakuska itp. (Zdanowicz i in. 1861, Karłowicz, Kryński, Niedźwiedzki (red.) 1900-1927, Doroszewski (red.) 1958-1969, Karaś 1996).

Uznanie tego rodzaju bohemizmów i rusycyzmów za pożyczki formalnosemantyczne (czasem explicite, a czasem milcząco, tzn. wobec braku komentarza sugerującego inną interpretację) oznacza, że przyjmuje się (w wypadku niektórych monografii stwierdzając to expressis verbis), iż w procesie zapożyczenia miała tu miejsce substytucja, odpowiednio: $g \mathrm{w}$ miejsce czeskiego $h$ (golicz - holič, pogrobek - pohrobek), e lub a (po spółgłosce twardej, a więc z pierwotnej nosówki tylnej) w miejsce czeskiego $u$, ou (łęczyszcze - lučišče, $s q d z k i$-soudský), e (po spółgłosce miękkiej, a więc z pierwotnej nosówki przedniej) w miejsce czeskiego $a, e$ (mięsopust - masopust, piędzimiężyk piedimužik, przesięgnać - presáhnouti), miękkiej spółgłoski zamiast twardej (z pierwotnej miękkiej) w języku czeskim (mięsopust - masopust, pierworodzeniec-prvorozenec, przesięgnać - přesáhnouti), -ło- w miejsce czeskiego 
-la- (obłocznica-oblačnice), -er-w miejsce czeskiego -r- (pierworodzeniec - prvorozenec), $d z \mathrm{w}$ miejsce czeskiego $z$ (pierworodzeniec-prvorozenec) itp., prze- w miejsce rosyjskiego pro- (przejaw - projav) lub pere- (przewózka-perevozka), wy- w miejsce rosyjskiego iz- (wyrozchodować-izraschodovat'), -ek w miejsce rosyjskiego -ok (uczastek - učastok), q zamiast rosyjskiego $u$ lub a po spółgłosce miękkiej (zakaska - zakuska, uczastek učastok), ro- (etymologicznie nagłosowego) zamiast rosyjskiego ra- (obróbka - obrabotka, wyrozchodować-izraschodovat') itp. Innymi słowy, przyjmuje się, że w procesie zapożyczania miała tutaj miejsce substytucja na zasadzie etymologicznej (na zasadzie regularnych międzyjęzykowych odpowiedniości fonetycznych o genezie etymologicznej).

Moim zdaniem, taka substytucja na zasadzie regularnych odpowiedniości etymologicznych jest w procesie zapożyczania wykluczona. Substytucja w procesie zapożyczania polega na zastępowaniu fonemów obcego języka rodzimymi fonemami identycznymi lub możliwie najbliższymi pod względem brzmieniowym - jak to w modelowym ujęciu ukazaliśmy na wstępie na przykładzie peruki. Dotyczy to także substytucji w zapożyczeniach z języków blisko spokrewnionych. Wyznawcy poglądu o substytucji na zasadzie regularnych odpowiedniości etymologicznych powołują się w tym kontekście na to, że na obszarach bi- lub multilingwalnych istnieje wśród użytkowników funkcjonujących tam języków - w różnych wzajemnych układach i związkach - świadomość międzyjęzykowych odpowiedniości etymologicznych. Liczne i wiarygodne wzmianki w literaturze przedmiotu skłaniają do uznania tego zjawiska za bezsporne. $Z$ drugiej strony nie ulega jednak wattpliwości, że ta świadomość nie wpływa na sposób przejmowania wyrazów z jednego języka do drugiego. W formie rubel (wcześniej, już w XVI wieku, rubl) mamy $u$ (jako fonem identyczny brzmieniowo z ruskim $u$ lub mu najbliższy) na miejscu ruskiego $u$, choć etymologicznie odpowiadałaby mu w tej formie tylna nosówka a. Tak samo mamy rubież, a nie *rabiez, ruczaj, a nie *rqczaj, holubić, a nie *gołębić i setki podobnych przykładów; również z języka czeskiego mamy hojny z bliskim czeskiemu $h$, a nie *gojny, masarz, a nie *mięsarz, rusznica z pierwotnego rucznica, a nie *ręcznica i dziesiątki tego rodzajów przykładów. A zatem bardzo liczne przykłady dowodzą, że również w procesie zapożyczania wyrazów z języków blisko spokrewnionych substytucja obcych fonemów odbywa się na zasadzie identyczności lub bliskości brzmieniowej, a nie na zasadzie regularnych odpowiedniości etymologicznych. 
Jakie są zatem źródła poglądu o substytucji etymologicznej w procesie zapożyczania wyrazów z języków blisko spokrewnionych i jakie uzasadnienie przywołują jego zwolennicy? Jak się wydaje, pogląd ten rozpowszechnił się w związku z przyjmowanym jeszcze do niedawna objaśnieniem postaci wyrazu król w różnych językach słowiańskich. Według od dawna i powszechnie przyjętej etymologii źródłem tego wyrazu było imię Karola Wielkiego, germańskie (frankijskie) Karl (choć dla ścisłości trzeba przypomnieć, że istnieje również alternatywne objaśnienie etymologiczne króla, autorstwa Mikołaja Rudnickiego (Rudnicki 1961, 1966), który uważa go za prasłowiański wyraz rodzimy: miałby on (*korl'b) pochodzić od czasownika *koriti 'korzyć', co by się motywowało prymarną władzą sądowniczą króla - pierwotnie najwyższego sędziego). Dopóki się powszechnie przyjmowało, że metateza (i/lub wzdłużenie) w prasłowiańskich grupach TărT, TălT (według dawniejszych poglądów TorT, TolT) była procesem bardzo dawnym, dopóty istotnie nie istniała inna możliwość wyjaśnienia postaci wyrazu król w różnych językach słowiańskich, jak przyjęcie wędrówki tego wyrazu od języka do języka (z zachodu na południe i wschód) z substytucją na zasadzie odpowiedniości etymologicznych: w myśl tej koncepcji germańskie (frankijskie) Karl mieliby w tej postaci przejąc Słowianie połabscy, jako zgodne z ich własnymi formami typu gard, varna; od nich mieliby je przejąć przodkowie Czechów w postaci $\mathrm{kral}$, na zasadzie odpowiedniości etymologicznych zgodnie ze swoimi formami typu grad (przejście $g \rightarrow h$ nastąpiło dopiero w XII-XIII wieku), vrana, i przodkowie Polaków w postaci krol, zgodnie ze swoimi formami typu grod, wrona, od nich z kolei plemiona ruskie w postaci korol', zgodnie ze swoimi formami typu gorod, vorona itp. (Lehr-Spławiński 1927) (w przytoczonych postaciach króla i paralelnych wyrazów w różnych językach słowiańskich abstrahuję od innych (poza grupą TărT) szczegółów fonetycznych, na przykład od faktu, że na przełomie VIII i IX wieku i król, i gród musiały się jeszcze wszędzie kończyć jerami - król miękkim, a gród twardym). Jednak dzisiaj, gdy wiemy, że metateza (i/lub wzdłużenie) w grupach TărT, TălT jeszcze na przełomie VIII i IX wieku była żywym procesem fonetycznym, nie ma żadnych przeszkód, by postaci wyrazu król w różnych językach słowiańskich traktować jako rezultat regularnego rozwoju fonetycznego (trzeba po prostu uznać, że zapożyczona forma *kărl'b na różnych obszarach Słowiańszczyzny rozwinęła się zgodnie z właściwym każdemu obszarowi rozwojem grupy TărT). Nie ma więc absolutnie żadnych podstaw, by przyj- 
mować tutaj substytucję na zasadzie regularnych odpowiedniości etymologicznych (Stieber 1966).

Jak zatem wyjaśnić postać takich zapożyczeń jak golicz czy pogrobek z czeskiego holič, pohrobek lub zakaska czy uczastek z rosyjskiego zakuska, učastok? Osobiście nie mam w tym względzie żadnych wątpliwości: nie są to zapożyczenia formalnosemantyczne (a więc w grę nie wchodzi substytucja poszczególnych fonemów), lecz kalki strukturalne (słowotwórcze). Mechanizm ich przejmowania polega więc na odwzorowywaniu ich budowy, tzn. na zastępowaniu obcych morfemów odpowiadającymi im pod względem znaczeniowym (funkcjonalnym w wypadku morfemów gramatycznych) morfemami rodzimymi. A zatem czeskie hol-ič zostało skalkowane w postaci gol-icz, czeskie luč-išč-e w postaci tęcz-yszcz-e i podobnie dalej: mas-o-pust i mięs-o-pust, ob-łocz-n-ic-a i ob-lač-n-ic-e, prv-o-roz-en-ec i pierw-o-rodzeni-ec, pied-i-muž-ik i piędz-i-męż-yk, po-hrob-ek i po-grob-ek, pře-sáh-nouti i prze-sięg-nq-ć, soud-sk-ý i sq(dz)k-i, itp. Tak samo rzecz się ma z przykładami rosyjskimi: $o b-r a b-o t-k-a$ i ob-rób-k-a (choć tu kalka jest niedokładna, gdyż w procesie kalkowania został pominięty jeden z morfemów wyrazu-wzorca), pro-jav i prze-jaw, pere-voz-k-a i prze-wóz-k-a, u-čast-ok i u-czastek, iz-ras-chod-ov-a-t' i wy-roz-chod-ow-a-ć, za-kus-k-a i za-kas-k-a itp. Wszędzie tutaj dochodzi do zastępowania morfemów czeskich lub rosyjskich ich polskimi odpowiednikami znaczeniowymi (funkcjonalnymi w wypadku morfemów gramatycznych), najoczywiściej zachodzi zatem proces kalkowania. Oczywiście, te polskie morfemy odpowiadają czeskim czy rosyjskim nie tylko semantycznie (funkcjonalnie w wypadku morfemów gramatycznych), jak to jest w wypadku kalk z języków niespokrewnionych lub połączonych odleglejszym pokrewieństwem, lecz także (choć nie zawsze, por. polskie wyi rosyjskie $i z$-) etymologicznie oraz w znacznej mierze fonetycznie - ale to już jest właśnie skutkiem bliskiego pokrewieństwa, a więc swoistą cechą kalkowania w sytuacji kontaktu języków blisko spokrewnionych.

Zagadnienie, które jest przedmiotem niniejszego szkicu, przedstawiłem - w obszerniejszej wersji - już wcześniej (Walczak 1999). Ponieważ jednak moja interpretacja zapożyczeń typu zakąska pozostała chyba niezauważona, uznałem za zasadne przypomnieć w skrócie mój wywód, który w tomie poświęconym specjalnie wpływom obcym w językach słowiańskich ma szansę zwrócić uwagę zainteresowanych tą problematyką slawistów. 


\section{Bibliografia}

Basaj M., Siatkowski J., 2006, Bohemizmy w języku polskim. Słownik, Warszawa: Wydawnictwo Wydziału Polonistyki Uniwersytetu Warszawskiego.

Doroszewski W. (red.), 1958-1969, Stownik języka polskiego, t. 1-11, Warszawa: Wiedza Powszechna.

KARAŚ H., 1996, Rusycyzmy stownikowe w polszczyźnie okresu zaborów, Warszawa: Wydawnictwo Uniwersytetu Warszawskiego.

KarŁowicz J., Krý́ski A., Niedźwiedzki W. (red.), 1900-1927, Slownik języka polskiego, t. 1-8, Warszawa: E. Lubowski.

LeHr-SpŁAwiŃSki T., 1927, Pochodzenie i rozpowszechnianie wyrazu „król” w polszczyźnie i innych językach słowiańskich, Prace Filologiczne XII, s. 44-53.

Mayenowa M. R. (red.), 1966-2004, Stownik polszczyzny XVI wieku, t. 1-32, Wrocław-Warszawa-Kraków: Wydawnictwo Zakładu Narodowego im. Ossolińskich.

Obara J., 1989, Teoretyczne problemy kalkowania, Wrocław: Wydawnictwo Uniwersytetu Wrocławskiego.

Rudnicki M., 1959-1961, Prastowiańszczyzna - Lechia - Polska, t. 1-2, Poznań: Wydawnictwo Poznańskiego Towarzystwa Nauk.

RuDNicki M., 1966, Najazd gocki na dorzecze Wisły około początków naszej ery, Slavia Occidentalis XXII, s. 41-47.

Stieber Z., 1966, O „królu”, „dziękowaniu” itp., w: Studia językoznawcze poświęcone doktorowi Stanisławowi Rospondowi, Wrocław-Warszawa-Kraków: Wydawnictwo Zakładu Narodowego im. Ossolińskich, s. 75-77 (przedruk w: STIEBer Z., 1974, Świat językowy Stowian, Warszawa: Państwowe Wydawnictwo Naukowe, s. 304-306).

URBAŃCZYK S. (red.), 1953-2002, Stownik staropolski, t. 1-11, Warszawa: Wydawnictwo Zakładu Narodowego im. Ossolińskich.

Walczak B., 1980, O rozwoju znaczeniowym zapożyczeń, w: M. Preyzner (red.), Język. Teoria-dydaktyka, Kielce: Wydawnictwo Wyższej Szkoły Pedagogicznej w Kielcach, s. 159-187.

Walczak B., 1983, O rozwoju znaczeniowym zapożyczeń leksykalnych, Sprawozdania Poznańskiego Towarzystwa Przyjaciót Nauk, Wydział Filologiczno-Filozoficzny 97-99, s. 137-142.

WalczaK B., 1989, Paralele w rozwoju znaczeniowym galicyzmów w języku polskim i rosyjskim, w: M. Basaj (red.), Paralele w rozwoju słownictwa języków słowiańskich, Wrocław-Warszawa-Kraków-Gdańsk-Łódź: Wydawnictwo Zakładu Narodowego im. Ossolińskich, s. 77-93.

WalczaK B., 1999, Zapożyczenia leksykalne (formalnosemantyczne) czy kalki? O pewnym typie zapożyczeń w kontaktach języków blisko spokrewnionych, 
w: M. Blicharski, H. Fontański (red.), Stowotwórstwo, semantyka i sktadnia języków stowiańskich, Katowice: Wydawnictwo Uniwersytetu Śląskiego, s. 124-133. Zdanowicz A. i in., 1861, Stownik języka polskiego, t. 1-2, Wilno: Wydawnictwo Maurycego Orgelbranda.

\section{Specific character of loanwords from cognate languages (a case study of Czech and East-Slavonic loanwords in Polish language) ( s u m mary)}

The author discusses the status of loanwords in cognate languages on the basis of Czech and Russian loanwords in Polish e.g. Polish zakaska 'snack, starter' from Russian zakuska 'hors d'oeuvre'. Such borrowings are usually considered to be lexical (formal-semantic) loanwords, where foreign phonemes have been regularly replaced with the etymologically corresponding phonemes. The author provides evidence that in fact we deal here with the phenomenon of structural calques. 